\title{
Introduced Alien Plant Species in the Neotropics: the Panama Case
}

\author{
Omar R. Lopez ${ }^{1,2, *}$ \\ ${ }^{1}$ Smithsonian Tropical Research Institute, Centro de Ciencias Forestales del Trópico, Apartado 0843-03092. Balboa, \\ Ancón, Panamá, República de Panamá \\ ${ }^{2}$ Centro de Biodiversidad y Descubrimiento de Drogas, Unidad de Ecología Aplicada, Instituto de Investigaciones \\ Cientificas y Servicios de Alta Tecnología (INDICASAT-AIP), Apartado 0843-01103. Ciudad del Saber, Clayton, \\ Panamá, República de Panamá
}

\begin{abstract}
Non-insular tropical biomes appear relatively resistant to invasive alien species (IAS). While some argue fewer IAS in continental tropical communities is the result of the complexity of species-rich communities (e.g., Elton's biological resistance hypothesis), others suggest lack of IAS might reflect fewer invasion opportunities, which could change with time. In effect, deforestation may lead to the simplification of tropical habitats, thus reducing biological resistance. Little is known about the current status of alien plants species, factors contributing to their spread and IAS in non-insular tropical systems. Here I report on the status of alien plant species in relation to area, number of native and endemics species, population, forest cover and cultivated area across provinces of Panama. Alien plant species comprise nearly 4 percent of the flora and was positively correlated with the number of native plant species $(r=0.84, P<0.001)$ and while this pattern runs counter to Elton's premise, it is consistent with other landscape-scale studies. In Panama, the number of alien plant species is explained by population density $(r=0.91, P<0.01)$ and potentially linked to disturbance, albeit coarsely, as the proportion of aliens negatively correlates with forest cover $(r=0.69, P<0.05)$. Thus, despite high diversity, these results portray disturbed tropical forests becoming dotted with introduced alien species. While few species seem to become invasive in the continental tropics, rapid land use change could promote the success of IAS representing serious consequences for tropical countries' economies and biodiversity.
\end{abstract}

Keywords: Biological resistance, disturbance, exotics, forest cover, herbarium, human population, land use change.

\section{INTRODUCTION}

Over the last five hundred years, humans have greatly altered natural landscapes by increasing disturbance regimes and facilitating species migration (Solbrig, 1994; Orians et al., 1996; Lodge, 1993). In conjunction, these two factors are linked to the successful establishment and rapid spread of many alien species (Fox and Fox, 1986). While an introduction event does not warrant successful establishment, introduced species are of concern due to their potential to become invasive, or better; invasive alien species (IAS), - defined here as non-native, non-indigenous species that rapidly propagate in a new environment having negative consequences for native ecosystems, economies and human welfare. IAS are now broadly recognized as a major threat to biodiversity and ecosystem services (e.g., water, food supply, air quality, public health, etc.).

At a global scale, both the number and proportion of alien species appears to be larger in temperate than tropical regions, with the exception of tropical oceanic islands (Simberloff, 1995; Rejmanek, 1998; Lonsdale, 1999; Fine, 2002; Pyšek et al., 2008). While this latitudinal asymmetry is most commonly explained by Elton's biological resistance

*Address correspondence to this author at the Centro de Biodiversidad y Descubrimiento de Drogas, Unidad de Ecología Aplicada, Instituto de Investigaciones Científicas y Servicios de Alta Tecnología (INDICASATAIP), Apartado 0843-01103. Ciudad del Saber, Clayton, Panamá, República de Panamá; Tel: 507-6948-9613; E-mail: prioria@yahoo.com hypothesis -the premise that diverse, complex communities better resist invasion by introduced alien species than species-poor, simpler communities (Elton, 1958), other factors might be involved. For example, history (e.g., steamship routes; Mack, 2003) as well as economical factors (e.g., trade; Meyerson and Mooney, 2007) might have influenced propagule pressure - the quantity and frequency at which an organism is introduced (see Lockwood et al., 2005). However, simplification of tropical communities by human-driven shifts in land use, disturbance, increased propagule pressure from growing international trade, as well as natural disturbance via climatic variability i.e., recurrent severe droughts and floods associated to El Niño Southern Oscillation (ENSO) may render tropical habitats more susceptible to the successful establishment and invasion by alien species in the future.

Management, conservation, and restoration of tropical ecosystems faces serious challenges. The neotropics, for example, holds one of the highest rates of conversion of species rich forests into simpler, pasture and crop land systems (Wassenaar et al., 2007). In addition, the fact that a great percentage of the population in the Neotropics depends directly on services that forested ecosystems offer (e.g., water, forest products extraction, hunting, fishing, etc.) poses a severe threat to biodiversity as well as human sustainability. However, the irreversible changes that IAS can cause to ecosystem properties and forest regeneration are generally overlooked in the continental tropics. IAS 
Table 1. Pairwise Correlation Coefficients among Species, Area and Explanatory Variables for all 10 Provinces of Panama. Significant Correlations $(P<0.05)$ are Shown in Boldface Type

\begin{tabular}{|c|c|c|c|c|c|c|c|c|c|c|c|}
\hline & Natives & Endemics & Aliens & Area $^{1}$ & Population & Cover $^{2}$ & Cultivated $^{3}$ & $\begin{array}{c}\% \\
\text { Aliens }\end{array}$ & P. Density ${ }^{5}$ & $\%$ Cover $^{6}$ & $\%$ Cultivated $^{7}$ \\
\hline Natives & - & 0.97 & 0.82 & 0.61 & 0.65 & 0.36 & 0.43 & 0.43 & 0.63 & 0.16 & -0.17 \\
\hline Endemics & & - & 0.84 & 0.52 & 0.71 & 0.26 & 0.42 & 0.41 & 0.71 & 0.18 & -0.19 \\
\hline Aliens & & & - & 0.46 & 0.94 & 0.23 & 0.25 & 0.39 & 0.91 & 0.09 & -0.19 \\
\hline Area $^{1}$ & & & & - & 0.35 & 0.86 & 0.19 & -0.20 & 0.19 & 0.33 & -0.37 \\
\hline Population & & & & & - & 0.10 & 0.21 & 0.36 & 0.96 & -0.04 & -0.11 \\
\hline Cover $^{2}$ & & & & & & - & -0.28 & -0.49 & -0.05 & 0.65 & -0.64 \\
\hline Cultivated $^{3}$ & & & & & & & - & 0.66 & 0.22 & -0.64 & 0.69 \\
\hline$\%$ Alien $^{4}$ & & & & & & & & - & 0.47 & -0.69 & 0.73 \\
\hline P. Density ${ }^{5}$ & & & & & & & & & - & -0.09 & -0.03 \\
\hline$\%$ Cover $^{6}$ & & & & & & & & & & - & -0.94 \\
\hline \% Cultivated ${ }^{7}$ & & & & & & & & & & - & - \\
\hline
\end{tabular}

${ }^{1}$ Province area in $\mathrm{km}^{2} ;{ }^{2}$ Forest cover in $\mathrm{km}^{2} ;{ }^{3}$ Total cultivated area of main grains (rice, corn and beans) in $\mathrm{km}^{2} ;{ }^{4}$ Percentage of alien species in relation to native species; ${ }^{5}$ Population density given by the number of habitants by $\mathrm{km}^{2} ;{ }^{6}$ Percentage of forest cover remaining in relation to total province area; ${ }^{7}$ Percentage of cultivated area in relation to total province.

represents a new challenge for conservation efforts in a region where most of the world's biodiversity and more than one third of the population of the planet resides (Cohen and Small, 1998). But, how common are IAS in the continental tropics? Our limitation to answer question arise, in part, to lack of basic information regarding introduced alien species, their natural history, potential impacts and alternative management strategies in tropical countries and their ecosystems.

This paper aims at reporting on the current status of alien plant species in Panama, Central America. Given its role as an important international trade route for over 100 years (McCullough, 1977; Ruiz et al., 2006), high biodiversity and recent appeal as a major tourist destination (Casado, 2001), Panama has potential as a model country for the study, longterm monitoring and management of introduced alien species in the tropics. I start by examining the abundance of alien species by political provinces in relation to regional scale predictors (i.e., area, total number of native and endemics species). To determine what factors are likely to influence the successful establishment of alien species in Panama, I assess how human population, forest cover, and cultivated area of primary agricultural products (e.g., rice, corn and beans) might predict the number of alien plant species.

\section{MATERIAL AND METHODS}

\subsection{Study Site and Species}

The Republic of Panama lies between $7^{\circ}$ and $10^{\circ}$ latitude North and $77^{\circ}$ and $83^{\circ}$ longitude East, comprising a total land area of $74,927 \mathrm{~km}^{2}$. Information on alien species of Panama was compiled from Correa et al. (2004). This report represents the most updated and official list of vascular plants in the Republic of Panama (i.e., voucher specimens at the National Herbarium, University of Panama). The information compiled in Correa et al. (2004) provides data on the total number of species (e.g., natives, endemics and aliens) per province. Although the political division of the country has changed recently, most information regarding plant distribution has been obtained and maintained using a system of 9 political provinces, one Indian reservation
-Guna Yala (formerly known as San Blas) - and the former Canal Zone. Because the former Canal Zone territory actually lies in the provinces of Panama and Colon, I used the fraction of alien species in these provinces represented in the Canal Zone to estimate the number of species to be included as part of the Panama and Colon provinces. It must be noted that there is considerable biases in Herbarium collections (i.e., ignoring 'known' exotic species in favor of native species) as personnel might have prioritize knowledge of native and endemic species over aliens. This might concomitantly promote avoidance of disturbed sites and further underestimation of alien species. While information from Correa et al. (2004) does not provide a direct assessment of a species' habitat, occurrence, abundance or distribution, it is our best, albeit coarse, assessment on the status of most alien species in Panama up to 2004.

Information on human population and cultivated area per province was obtained from the Department of Censuses and Vital statistics of the General Comptroller Office of the Republic of Panama (http://www.contraloria.gob.pa/dec/) for the year 2002. Population per province represents the total number of inhabitants in that province. Information on province area and forest cover was obtained from a national report on forest cover and land use of the Republic of Panama (ANAM, 2003) and represents the total area of square kilometers that include some type of forest cover, which includes mature forest, secondary forest and scrubland.

\subsection{Statistical Analysis}

A multivariate Pearson's product-moment correlation analysis was performed across variables using both; total and area-standardized data (see results Table 1). However, to test which of the explanatory variables (e.g., forest cover, cultivated land, and population) best predicts the abundance and proportion of alien species, I used Akaike's Information Criterion (AIC) to select the best suite of explanatory variables from all possible models. AIC is an informationtheoretic approach that allows selection of the most parsimonious model that adequately fits the data -the model with the lowest AIC. This approach is more robust than the traditional stepwise methods for selecting variables to 

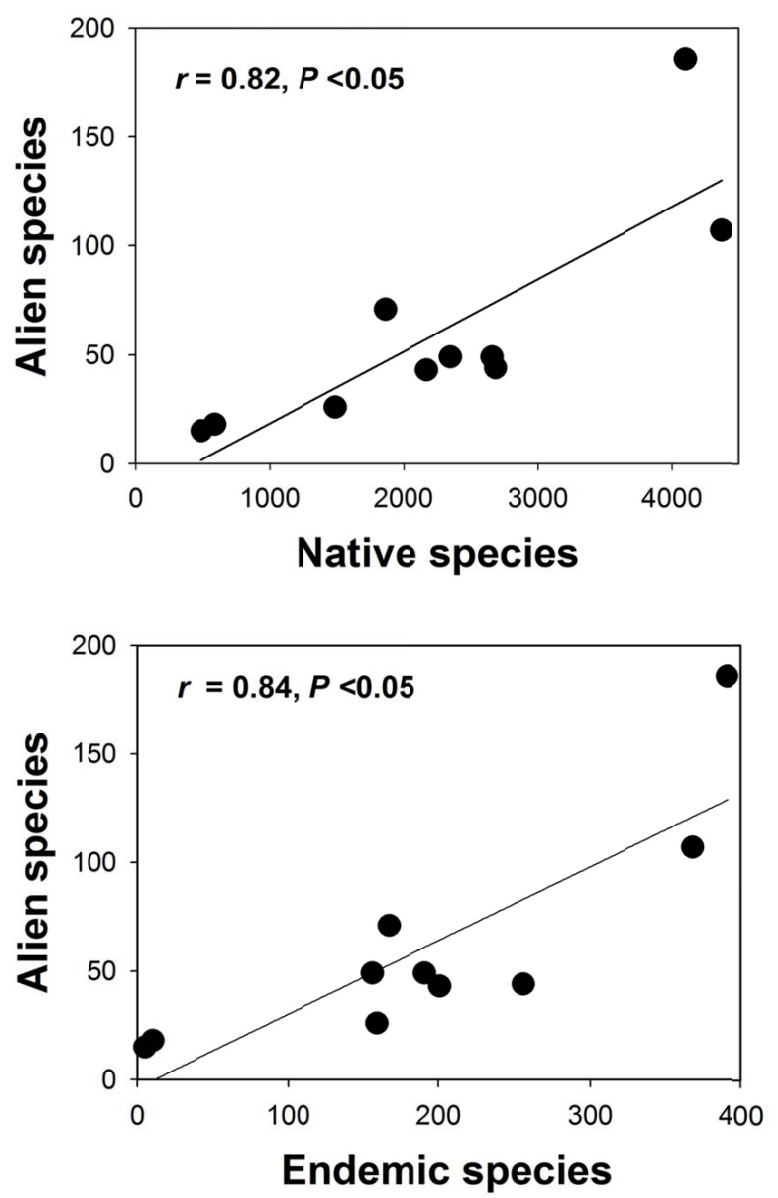

Fig. (1). Pearson product-moment correlation between the total number of alien species and native (A) and endemic species (B), across 10 political provinces of Panama. Each point represent the total number of plant species of each category reported for each province at the National Herbaria summarized by Correa et al., 2004 (see methods section).

include in a model, therefore avoiding the problem of overfitting — and indirectly, collinearity — as it places a penalty on the number of parameters used in the model (see Rushton et al. 2004). AIC was applied to a set of a priori models where the effect of area is removed. Therefore, explanatory variables are standardized by area across provinces expressing the proportion of alien species [alien species/native species] per province in relation to; the proportion of forest cover [forest cover area/province area in $\mathrm{km}^{2}$ ], the proportion of agricultural land [cultivated area/province area in $\mathrm{km}^{2}$ ] and population density [habitants/province area in $\mathrm{km}^{2}$ ]. I further applied a correction to the $\mathrm{AIC}$ for small sample sizes, termed $\mathrm{AIC}_{\mathrm{c}}$ and compared the models using the estimated delta AIC on the corrected scores termed $\Delta_{i}$ (Burnham and Anderson 2004). A total of 4 models were used, among which comparison of $\mathrm{AIC}_{\mathrm{c}}$ 's and $\Delta_{i}$ 's is reported. All statistical analysis were conducted using R v 2.4.0 (2008).

\section{RESULTS}

In Panama there are a total of 9,520 species of vascular plants of which 373 are known alien species (i.e., 4\%; Correa et al. 2004). Alien species was significantly
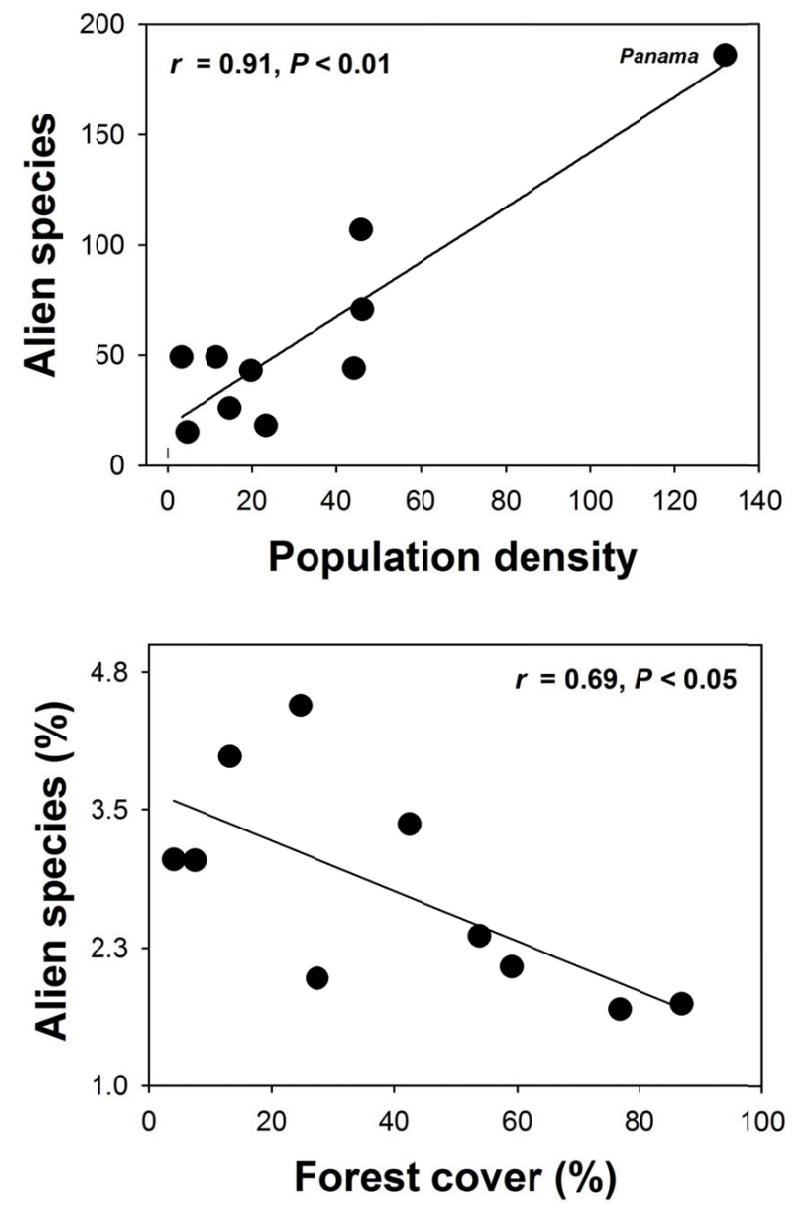

Fig. (2). Pearson product-moment correlation between the total number of alien species vs. population density (A) and the proportion of alien species in relation to the remaining forest cover (B), across 10 political provinces in Panama. The percentage of aliens represents the total number of alien plant species divided by the total of native species in each province.

correlated with the total number of native and endemic species reported for each political province (Table 1; Fig. 1A and $\mathbf{B}$, ). Pairwise correlation analysis among explanatory variables also reveals that the number of alien species was significantly correlated with population and population density, while the percentage of aliens showed a negative correlation with the proportion of forest cover (Table 1; Fig. $\mathbf{2 A}$ and $\mathbf{B}, r=0.91, P<0.001$ and $r=-0.69, P<0.05$, for population density and the proportion of forest cover, respectively). Although, the relationship between aliens and population density appears to be driven by Panama, a province with nearly $50 \%$ of the country's population, once removed from the analysis the relationship remains significant.

The use of the Akaike's Information Criterion reveals that the percentage of forest cover in conjunction with population density generates the most parsimonious (i.e., simplest) model for predicting the proportion of alien plant species across provinces of Panama. That is evidenced by the lowest $\Delta_{i}$ value among all competing models (Model ${ }_{1}$ $\mathrm{AIC}_{\mathrm{c}}=29.18$; see Table 2). However, the AIC approach 
Table 2. Corrected Akaike's Information Criterion $\left(\mathrm{AIC}_{\mathrm{c}}\right)$ and Delta $\mathrm{AIC}_{\mathrm{c}}\left(\Delta_{i}\right) \mathrm{Scores}$ for Selected Models. Models 1-4, Represent those where all Explanatory Variables have been Standardized by Province Area to Predict the Proportion of Alien Plant Species Per Province (see Methods)

\begin{tabular}{|c|c|c|c|}
\hline Model Considered & Df & $\mathbf{A I C}_{\mathrm{c}}$ & $\Delta_{i}$ \\
\hline $\mathrm{M}_{1 \% \text { Aliens }}=\%$ Cover + P. Density & 4 & 29.18 & 0.00 \\
\hline $\mathrm{M}_{2 \% \text { Aliens }}=\%$ Cover $+\%$ Cultivated & 4 & 32.78 & 3.60 \\
\hline $\mathrm{M}_{3 \% \text { Aliens }}=\mathrm{P}$. Density $+\%$ Cultivated & 4 & 29.47 & 0.29 \\
\hline $\mathrm{M}_{4 \% \text { Aliens }}=\%$ Cover $+\%$ Cultivated $+\mathrm{P}$. Density & 5 & 32.52 & 3.34 \\
\hline
\end{tabular}

Aliens $=$ total aliens, Area $=$ province area in $\mathrm{km}^{2}$, Cover $=$ forest cover in $\mathrm{km}^{2}$, Cultivated $=$ land of main grains e.g., rice, corn, beans in $\mathrm{km}{ }^{2}$, P. Density $=$ number of habitants per km

generates very little resolution between $\mathrm{Model}_{1}$ and a $\mathrm{Model}_{3}$ where the proportion of agricultural land and population density become the main drivers for explaining alien species across provinces (Table 2). Although the great majority of alien species $(67.6 \%)$ are reported as cultivated either for agriculture, gardening, medicinal or for folkloric use, I found that nearly five percent of all aliens ( 18 species) are recognized as invasive elsewhere (see Table 3 for a list of some of these species).

\section{DISCUSSION}

Across all provinces, alien plant species represent nearly 4 percent of the flora of Panama, ranging from 1.6 to 4.5 percent. These numbers are considerably lower than the global mean value of 16 percent reported in Lonsdale (1999), and that of neighboring Costa Rica, a country with similar plant diversity, geography and demographics, where aliens make up to 10 percent of the flora (Chacón and Saborio 2006). While Costa Rica holds a 3.5 times higher deforestation rate and nearly $11 \%$ less forest cover than Panama (estimated for the period 1990-2000; Butler 2009), the discrepancy in the number of aliens may lie on Costa Rica's recent botanical sampling efforts and not in deforestation per se. In 1989 Costa Rica launched a national initiative to inventory and catalogue their biodiversity wealth with a particular emphasis on plants. Such efforts might have increased the number of aliens reported; as much as $20 \%$ of the flora might have been identified and described in the last two decades (Tangley 1990, Green 2004). Without a thorough inventory it is difficult to assess what total percentage of the flora is alien and which species can be considered invasive, however many alien species occurring in Panama are reported as invasive or problematic elsewhere (Table 3). Pyšek (2008), has recently emphasized the importance of tracking ornamentals in IAS research programs in order to gain knowledge about "innocuous" species that might become invaders. Thus, our assessment not only underestimates total number of aliens, but underscores a pressing need for base-line research and longterm monitoring on introduced alien species in Panama and the region.

Across all political provinces of Panama, alien species might be better explained in relation to human population density. However, once the explanatory variables are standardized by area, the fraction of remaining forest cover together with population density becomes the most important variables in explaining alien species number. This finding, together with newly available information on invasive species generated by regional initiatives (Inter-American Biological Information Network 2008) suggests that alien species are becoming widespread across tropical landscapes. Yet, some of the results presented here should be taken cautiously given the potential skewness nature of Herbarium data (see Methods) and the number of observations taken. Despite this, in Panama and Central America for example, many aliens are well known invasives revealing the urgent need to create proficient mechanisms to quantitatively assess, monitor and implement management policies for alien species at the country and regional level.

The scarcity of IAS in continental tropical biomes has been attributed to Elton's biological resistance hypothesis (Elton 1958). This is, high species diversity might increase invasion resistance owing to increased competition for resources e.g., space, light, nutrients, etc. In this study, the number of alien species was found to be positively correlated to the total number of native species. This is congruent with other findings in which species-rich areas support more aliens (Lonsdale 1999, Eriksson et al. 2006, Westphal et al. 2008; but see Simberloff and Holle 1999). Yet, area might influence habitat heterogeneity and thus underlie this relationship (see Brose 2001), but the limitations of the data $(n=10)$ preclude us from detecting a clear pattern. Because population, forest cover and agricultural land may also covary with province area it might be inappropriate to assert that the correlation between alien and native plant species across Panama respond to the effects of area on habitat diversity alone. Alternatively, it is plausible that the competitive mechanism by which Elton's biological resistance hypothesis operates still affects alien species establishment (see Naeem et al. 2000).

Disturbance has become increasingly linked to the successful establishment of alien species in their new habitat (Fox and Fox 1986, Peters 2001, Bellingham et al. 2005). Thus, is there an indication of human-driven influence (direct or indirect) in the success of alien plant species in Panama? In this study, it appears that human population density significantly contribute to the number and proportion of alien species established in each province. This could be explained via two possible mechanisms. First, given that a great proportion $(67.6 \%)$ of the alien flora is cultivated, it is therefore expected that humans are significantly contributing to the spread of propagules and seeds of these species across Panama. Although we lack detailed quantitative data linking ornamental species to invasion, we must note that many of them might become invasive. In the Czech republic, 
Table 3. List of Problematic Alien Plant Species given by Family, Scientific Name, Growth Habit, Uses and Region of Origin Known to Occur in Panama that have been Reported as Invasive or Problematic Elsewhere. Nomenclature Follows Missouri Botanical Gardens

\begin{tabular}{|c|c|c|c|c|c|}
\hline Family & Species & Habit & Uses & Origin & Invasive in \\
\hline Apocynaceae & Cryptostegia madagascariensis Bojer ex. Dene. & Woody vine & Ornamental & Africa & USA $^{4}$, Pacific Islands ${ }^{2}$, Australia ${ }^{5}$ \\
\hline Balsaminaceae & Impatiens walleriana Hook. F. & Herb & Ornamental & Africa & Hawaii ${ }^{1}$, Pacific Islands ${ }^{2}$, USA $^{4}$ \\
\hline Bignonaceae & Tabebuia heterophylla (DC) Britton & Tree & Ornamental & Caribbean & Pacific Islands $^{2}$ \\
\hline Hydrocharitaceae & Hydrilla verticillata (L.f.) Royle & Aquatic herb & Aquarium & Africa/Asia & USA $^{4}$, Pacific Islands ${ }^{2}$, Autralia ${ }^{3}$ \\
\hline Meliaceae & Melia azedarach $\mathrm{L}$. & Tree & Ornamental & SE Asia & $\mathrm{USA}^{4}$ \\
\hline Myrtaceae & Syzygium jambos (L.) Alston & Tree & Fruit & SE Asia & Hawaii $^{1}$, Pacific Islands ${ }^{2}$ \\
\hline Oleaceae & Ligustrum sinense Lour & Shrub & Ornamental & Asia (China) & $\mathrm{USA}^{4}$ \\
\hline
\end{tabular}

${ }^{1}$ Hawaiian Ecosystems at Risk 2012, ${ }^{2}$ Pacific Islands Ecosystems at Risk 2012, ${ }^{3}$ Global Invasive Species Database 2012, ${ }^{4}$ US Department of Agriculture $2012,{ }^{5}$ Weeds in Australia 2012.

naturalized ornamentals make more than 50 percent of the IAS (Pyšek et al., 2003). Second, alien species can be linked indirectly through human population pressure on land use changes via forest cover (i.e., deforestation) and increasing need for food (i.e., agricultural land). This is evidenced in the negative correlation between the proportion of forest cover to the proportion of alien plant species established in each province. Thus taken together, anthropogenic dispersal and human-driven forest transformation may facilitate the establishment, spread and potential invasion by naturalized ornamental species.

In the tropics, accelerated land use change, in particular forest transformation into simpler, pasture-like, less diverse systems pose severe threats to biodiversity. Forest cover removal could further erode tropical biome diversity facilitating alien species establishment. As a consequence, one might ask: How does deforestation influence alien species establishment? One possible reason is that forest cover removal facilitates the establishment and spread of alien species by freeing space for establishment. However, freeing of space might carry a twofold effect. First, it allows physical space for plant establishment by eliminating native species giving the new establishing alien species a transitional advantage for resource acquisition and growth without competition (Hobbs 1989). Alternatively, because the great majority of introduced alien species tend to be light demanding species (Fine 2002), it is likely that deforestation also create optimal light availability for fast growth. This has been the case of many invasive species such as Clidemia hirta (Melastomataceae), an invasive shrub in peninsular Malaysia that is restricted to light clearings (i.e., gaps) in the forests (Peters 2001). Also plausible, is the idea that forest deforestation and transformation contributes to alien species establishment via "weakening" of the biological resistance (sensu Elton 1958), however this remains to be tested as examination of Elton's postulate has not yet been evaluated in non-insular, diverse, tropical systems. Therefore, conservation and restoration of tropical forests face a new challenge: past, present and future transformation is likely to leave a tropical landscape interspersed with alien species, many of which might become invasive in the near future.

\section{IMPLICATIONS FOR CONSERVATION}

The present study reports on the distribution of introduced alien species in relation to human population (e.g., size and density) and the fraction of forest cover remaining across all political provinces of Panama. While it might be tempting to link successful establishment of alien plant species with invasion, the nature of the data (i.e., coarse, small sample size) prevent us from discerning in what type of tropical habitats invasion is likely to occur as not all tropical habitats - nor all habitats within Panama can be described as high diversity habitats. Nevertheless, the invasive examples given reinforce the need to delineate strategic policies, as well as research priorities to quantitatively asses the status of introduced aliens species at the country and regional level. Detailed, basic research on the status of alien plant species in the tropics is needed in order to confirm whether factors driving invasion patterns in temperate and insular regions also hold for the continental tropics.

\section{ACKOWLEDGEMENTS}

I would like to thank Rolando Pérez, Andrés Hernández, Rafael Aizprúa, Krista Lopez-Farris, Ingrid M. Parker, Jim Dalling and two anonymous reviewers for fruitful discussions on alien species and for comments on the manuscript. I am also grateful to Jörn Scharlemann for advice in the statistical analysis. This research was made possible by a grant from the National Secretariat for Science, Technology and Innovation of the government of the Republic of Panama (SENACYT - PRB-06-007), the support of the Center of Tropical Forest Science at the Smithsonian Tropical Research Institute in Panama and INDICASAT-AIP. 


\section{REFERENCES}

ANAM (2003) Informe final de resultados de la cobertura boscosa y uso del suelo de la República de Panamá: 1992-2000. Proyecto "Fortalecimiento Institucional del Sistema de Información Geográfica de la ANAM para la Evaluación y Monitoreo de los Recursos Forestales de Panamá con miras a su Manejo Sostenible" Autoridad Nacional del Ambiente (ANAM). Panamá.

Bellingham, PJ, Tanner, EVJ, Healey, JR (2005) Hurricane disturbance accelerates invasion by the alien tree Pittosporum undulatum in Jamaican montane rain forests. Journal of Vegetation Science 16, 675-684.

Brose, U, (2001) Relative importance of isolation, area and habitat heterogeneity for vascular plant species richness of temporary wetlands in east-German farmland. Ecography 24, 722-730.

Burnham, KP, Anderson, DR (2004) Multimodel inference: understanding AIC and BIC in model selection. Sociological Methods Research $33,261-304$

Butler, RA (2009) Tropical Rainforest: deforestation. http://rainforests.mongabay.com/deforestation [Accessed Jun. 24, 2012].

Cohen, J, Small, C (1998) Hypsographic demography: The distribution of human population by altitude. Proceedings of the National Academy of Sciences, USA 95, 14009-14014.

Casado, MA (2001) Overview of Panama's tourism in the aftermath of the turnover of the Canal Zone. Journal of Travel Research 40, 88-9.

Chacón, E, Saborío-R G (2006) Análisis taxonómico de las especies de plantas introducidas en Costa Rica. Lankesteriana 6, 139-147.

Correa, MD, Galdames, C, Stapf de MS (2004) Catálogo de Plantas Vasculares de Panamá. Quebecor World Bogotá, Colombia.

Elton, CS (1958) The Ecology of invasions by animals and plants. Methuen, London, UK.

Eriksson, O, Wikstrom, S, Eriksson, A, Lindborg, R (2006) Species-rich Scandinavian grasslands are inherently open to invasion. Biological Invasions 8, 355-363.

Esquivel, EA (2004) El origen de la paja canalera, Saccharum spontaneum L. en Panamá. Agrociencia Panamensis. No.34 Año III.

Fine, PVA (2002) The invisibility of tropical forests by exotic plants. Journal of Tropical Ecology 18, 687-705.

Fox, MD, Fox, BJ (1986) The susceptibility of natural communities to invasion. In R.H. Groves and J.J. Burdon (Eds.): Ecology of biological invasions, Cambridge University Press, London, UK. 57-66.

Global Invasive Species Database (2012). Invasive Species Specialist Group (ISSG) of the IUCN Species Survival Commission. http://www.issg.org/database/welcome [Accessed Jun. 24, 2012].

Green, P (2004). Biodiversity conservation in Costa Rica: the INBio experience. Microbiologist 5, 34 .

Hawaiian Ecosystems at Risk (HEAR) (2012) http://www.hear.org/ [Accessed Jun 24, 2012]

Hobbs, R J (1989) The nature and effects of disturbance relative to invasions. In Drake JA, Mooney HA, di Castri F, Groves RH, Kruger FJ, Rejmanek M, Williamsom M. (Eds.): Biological Invasions: a Global perspective, John Wiley, New York, NY. 389406.

IABIN (2008) Invasive Species Information Network (I3N). The InterAmerican Biodiversity Information Network (IABIN). http://i3n.iabin.net/ [Accessed Jun. 24, 2012].

Lockwood, JL, Cassey, P, Blackburn T (2005) The role of propagule pressure in explaining species invasions. Trends in Ecology and Evolution 20, 223-228.

Lodge, MD (1993). Biological invasions: lessons for ecology. Trends in Ecology and Evolution. 8, 133-137.

Lonsdale, WM (1999) Global patterns of plant invasions and the concept of invasibility. Ecology 80, 1522-1536.
McCullough, DG (1977) The path between the seas. Simon and Schuster, New York, NY.

Mack, RN (2003) Plant naturalizations and invasions in the eastern United States: 1634-1860. Annals of the Missouri Botanical Gardens 90 $77-90$.

Marshall, JT (1985) Guam: a problem in avian conservation. Wilson Bulletin 97, 259-262.

Meyerson, LA, Mooney, HA (2007) Invasive alien species in an era of globalization. Frontier in Ecology and the Environment 5, 199208.

Naeem, S, Knops, JMH, Tilman, D, Howe, KM, Kennedy, T, Gale, S (2000) Plant diversity increases resistance to invasion in the absence of covarying extrinsic factors. Oikos 91, 97-108.

Orians, GH, Dirzo, R, Cushman, JH (1996) Synthesis. In GH Orians, R. Dirzo and JH. Cushman (Eds.): Springer-Verlag, New York, NY. Ecosystem processes in tropical forests. Ecological Studies 122.

Pacific Islands Ecosystems at Risk (PIER), 2012. Available at: http://www.hear.org/pier/ [Accessed Jun. 24, 2012]

Peters, HA (2001) Clidemia hirta invasion at the Pasoh Forest Reserve: an unexpected plant invasion in an undisturbed tropical forest. Biotropica 33, 60-68

Pyšek, P, Sádlo J, Mandák, B (2003). Alien flora of the Czech Republic, its composition, structure and history. Plant Invasions: Ecological threats and management solutions, Backhuys Publishers, Leidon, The Netherland, 113-130.

Pyšek, P, Richardson DM, Pergl, J, Jarošík, V, Sixtová, Z, Weber, E (2008) Geographic and taxonomic biases in invasion ecology. Trends in Ecology and Evolution 23, 237-244.

R Development Core Team (2008) R: A language and environment for statistical computing. R Foundation for Statistical Computing, Vienna, Austria. Available at: http://www.R-project.org.

Rejmanek, M (1996) Species richness and resistance to invasions. In Orians GH, Dirzo R and Cushman JH (Eds.): Ecosystem processes in tropical forests. Ecological Studies, Springer-Verlag, New York, NY, 122 .

Ruiz, GM, Lorda, J, Arnwine, A, Lion, K (2006) Shipping patterns associated with the Panama Canal: effects on biotic exchange? In: Gollasch S, Galil BS, Cohen AN (Eds) Bridging divides-maritime canals as invasion corridors. Springer, Berlin, 113-126

Rushton, SP, Ormerod, SJ, Kerby, G (2004) New paradigms for modelling species distributions? Journal of Applied Ecology 41, 193-200.

Simberloff, D (1995) Why do introduced species appear to devastate islands more than mainland areas? Pacific Science 49, 87-97.

Simberloff, D, Holle, BV (1999) Positive interactions of nonindigenous species: invasional meltdown. Biological Invasions 1, 21-32.

Solbrig, OT (1994) Biodiversity: an introduction. In O.T. Solbrig, H.M. van Emden and P.G.W.J. van Oordt (Eds.): Biodiversity and global change, Centre for Agriculture and Bioscience, Oxon, UK. 13-20.

Tangley, L (1990) Cataloging costa rica's diversity. BioScience 40, 633636.

United States Department of Agriculture: Natural Resources Conservation Service, 2012. Available at: http://plants.usda.gov [Accessed Jun. 24, 2012]

Wassenaar, T, Gerber, P, Verburg, PH, Rosales, M, Ibrahim, M, Steinfeld, $\mathrm{H}$ (2007) Projecting land use changes in the Neotropics: The geography of pasture expansion into forest. Global Environmental Change 17, 86-104

Weeds in Australia, 2012. Department of the Environment, water, heritage and the arts of Australia. Available at: http://www.weeds.gov.au [Accessed Jun. 24, 2012]

Westphal, MI, Browne, M, MacKinnon, K, Noble, I (2008) The link between international trade and the global distribution of invasive alien species. Biological Invasions 10, 391-398.

Received: August 17, 2012

Revised: October 04, 2012

Accepted: October 06, 2012

(C) Omar R. Lopez; Licensee Bentham Open.

This is an open access article licensed under the terms of the Creative Commons Attribution Non-Commercial License (http://creativecommons.org/ licenses/by-nc/3.0/), which permits unrestricted, non-commercial use, distribution and reproduction in any medium, provided the work is properly cited. 